\author{
Marek Tatar \\ Uniwersytet Kardynała Stefana Wyszyńskiego w Warszawie \\ ORCID: 0000-0002-7161-8196
}

\title{
Biblijne podstawy eklezjalnej duchowości communio
}

\begin{abstract}
Abstrakt: Proces sekularyzacji i relatywizacji życia współczesnego człowieka dotyka wierzących w ich doświadczeniu Kościoła. Jednocześnie zauważalne jest zainteresowanie duchowością, ale często o charakterze zindywidualizowanym i pozaeklezjalnym. Stąd wynika konieczność refleksji nad właściwym rozumieniem tożsamości i misji Kościoła. Adekwatnym pojęciem dla opisania tej tożsamości jest communio. Artykuł wyjaśnia właściwe jego rozumienie w kluczu biblijnym ze względu na wieloznaczność, która występuje w publikacjach z zakresu teologii, a także w naukach pozateologicznych. Szczególnego znaczenia nabiera ono na gruncie teologii duchowości, określając charakter jedności pomiędzy Bogiem a człowiekiem. Analiza Starego Testamentu odsłania istotne aspekty komunijne wynikające z Przymierza. Analiza Nowego Testamentu wskazuje zaś, że w Jezusie Chrystusie dokonała się pełnia komunijnego zjednoczenia, która znajduje swoją kontynuację w Kościele. Z tego względu duchowość chrześcijanina musi być interpersonalna, chrystocentryczna, chrystoformiczna oraz eklezjalna. Ten proces kształtuje życie moralne, znajdujące swoje odzwierciedlenie w życiu indywidualnym, społecznym, ekonomicznym, a nawet politycznym.
\end{abstract}

Słowa kluczowe: duchowość biblijna, duchowość eklezjalna, duchowość chrześcijańska, świętość, communio, zjednoczenie, mistyka

\section{Wprowadzenie}

Wa gruncie współczesnej teologii znaczącą rolę odgrywa pojęa także jest odzwierciedleniem natury Kościoła oraz jego obecności w świecie. Refleksja nad coraz głębszym rozumieniem swojej istoty oraz natury jest treścią nauczania Kościoła w każdym czasie. Jego powołanie skierowane jest do świata, a jednocześnie musi on zachować właściwą sobie tożsamość wynikającą z jedności z Jezusem Chrystusem. Ta jedność pozwala mu zachować dystans wobec świata. $\mathrm{Na}$ gruncie tychże analiz pojęcie communio stało się kluczowe dla 
nauczania Soboru Watykańskiego II $^{1}$. Teologia communio znalazła swoje głębokie odzwierciedlenie na gruncie teologii dogmatycznej, moralnej czy też pastoralnej. Staje się ona nieodzowna dla teologii duchowości w jej analizie doświadczenia Boga, a także w konfrontacji ze współczesnymi wyzwaniami. Na duchowość komunii zwrócił uwagę Kościołowi i światu Jan Paweł II, uznając ją za kluczową drogę dążenia człowieka i świata do uświęcającej jedności z Bogiem w Jezusie Chrystusie i współpracy z Duchem Świętym. Na podkreślenie zasługują jego następujące słowa: „Czynić Kościół domem i szkołą komunii: oto wielkie wyzwanie, jakie czeka nas [...] jeśli chcemy pozostać wierni Bożemu zamysłowi, a jednocześnie odpowiedzieć na najgłębsze oczekiwania świata"2. Właściwe nakreślenie tej problematyki domaga się przede wszystkim doprecyzowania samego pojęcia. Konieczne zatem jest odwołanie się do podstaw biblijnych - zarówno Starego, jak i Nowego Testamentu. Jest to najbardziej właściwe źródło odsłaniające zamysł Boga wobec Kościoła, którego misja posiada charakter uświęcający, a jednocześnie sam jest on uświęcany. Możemy zatem stwierdzić, że jest podmiotem oraz przedmiotem procesu uświęcania.

\section{Kwestie terminologiczne - communio wierzących a naturalna społeczność}

Mimo że pojęcie communio nie należy do nowych na gruncie teologii i duchowości Kościoła ${ }^{3}$, należy stwierdzić, że poznawanie go podlega ciągłemu rozwojowi pod względem jakościowym, tzn. coraz głębszego jego znaczenia ${ }^{4}$. Każda z dziedzin teologii podejmuje w pełni uprawnioną refleksję nad jego znaczeniem w kontekście prowadzonych badań. Szczególnie ostatnie kierunki rozwoju teologii dogmatycznej chętnie odwołują się do tego pojęcia. Nie oznacza to prób relatywizowania go, ale jego bogactwo zastosowania zarówno w przestrzeni naukowo-badawczej, jak również teologiczno-pragmatycznej.

\footnotetext{
Por. J. Vik, „Communio”, 68-69.

Jan Paweł II, Novo millennio ineunte, 43.

3 Por. M. Jagodziński, Komunijna wizja, 129-135.

4 Por. R. Skrzypczak, „Kościół”, 174-175.
} 
W ogromnej przestrzeni nauk teologicznych znajduje ono także swoje właściwe miejsce na gruncie duchowości chrześcijańskiej. Opisuje charakter dynamicznego procesu uświęcającego, posiadającego właściwą sobie intensywność zjednoczenia z Bogiem, bliźnim i harmonii wewnętrznej samego człowieka, w zależności od etapu jego rozwoju duchowego ${ }^{5}$.

Łacińskie słowo communio oznacza ,wspólny udział, uczestniczenie, wspólnotę"6. Sięgając zaś do ujęć teologiczno-encyklopedycznych, nie znajdziemy jednoznacznego wyjaśnienia tego pojęcia. Pośrednio mówi o nim charakterystyka semantyczna angielskiego słowa „community"?.

$\mathrm{Na}$ gruncie teologii analiza tego pojęcia domaga się odwołania do zasadniczego źródła, którym jest objawienie Starego oraz Nowego Testamentu. W polskiej przestrzeni teologicznej ks. prof. M. Jagodziński, podejmując próbę jego wyjaśnienia, odwołał się do tekstów chrystologicznych Nowego Testamentu (por. 1 Kor 10,16; 2 Kor 13,13).

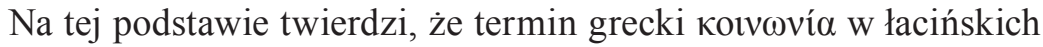
przekładach Nowego Testamentu został przetłumaczony jako communio i communicatio. Zaważa, że podejmując próbę jego wyjaśnienia, należy uwzględnić podwójną konotację metaforyczną, tj. odnoszącą się do rdzenia „mun” oznaczającego obwałowanie gromadzące ludzi nakierowanych na siebie oraz „munus” określającego zadanie, posługę, dar, poczęstunek, wzajemne zobowiązanie służby ${ }^{8}$. Na tej podstawie należy stwierdzić, że mamy do czynienia z elementami, które jednoczą, budują, scalają, a jednocześnie określają efekt tego procesu. Autor podaje w wątpliwość polskie tłumaczenie communio jako „wspólnota”. Z pewnością dogmatyk ma rację, twierdząc, że takie rozumienie opisuje efekt, a nie zasadniczą zawartość pojęcia. Z punktu widzenia duchowości należy zauważyć, że termin ten opisuje relacyjność tych, którzy tworzą wspólnotę w odniesieniu do osoby Boga oraz ze względu na Niego do drugiego człowieka.

\footnotetext{
5 Por. M. Tatar, „Wspólnotowy”, 112.

6 J. Korpanty (red.), Słownik łacińsko-polski, 126, hasło: Communio; R. Skrzypczak, „Kościół”, 175.

7 Por. J.A. Bracken, „Community”.

8 Por. M. Jagodziński, Sakramenty, 7; R. Skrzypczak, „Kościół”, 175; J. Vik, „Communio”, 70-71; M. Tatar, „Wspólnotowy”, 113.
} 
Wyjątkowy charakter tejże relacyjności polega na tym, że jest ona dynamiczna. Oznacza to, iż jest to proces komuniotwórczy, który urzeczywistnia się w konkretnych warunkach życia chrześcijanina, a także całego Kościoła9 .

Pewne uzupełnienie powyższego wyjaśnienia treści semantycznej communio odnajdujemy w analizie ks. prof. C. Bartnika. Lubelski teolog, również odwołując się do Pisma św. (por. Dz 2,42-47; 4,32-37; 1 Kor 1,9; 2 Kor 6,16; Ga 2,9), stwierdza, że jest to stara idea. Jednocześnie postuluje, aby uwzględnić istotne rozgraniczenie. Przyjmując tłumaczenie communio jako „wspólnota”, określamy ,jedność”, „wspólność”, ,związanie w całośćc” i odnosi się ono do pewnej zbiorowości ludzi. Dlatego w tym sensie może być użyte wobec każdej społeczności ${ }^{10}$. Jednocześnie zastrzega, że w tym kontekście określenie to posiada charakter socjologiczny. Taki sposób definiowania mówi o występującej więzi, ale nie mamy możliwości określenia jej kategorii czy też oceny moralno-etycznej. Ks. C. Bartnik twierdzi, że wymaga zastosowania dopowiedzenia w formie specyfikacji, np. wspólnota wolontariatu na rzecz pomocy niepełnosprawnym. W ten sposób właśnie to doprecyzowanie dokonuje właściwego rozróżnienia pomiędzy wspólnotą a społecznością. W pierwszym wypadku u podstaw znajduje się cała konstrukcja aksjologiczna wspólnototwórcza. Społeczność czy też społeczeństwo jako termin socjologiczny opisuje grupę ludzi związanych uwarunkowaniami, np. zamieszkaniem, zawodem itp. ${ }^{11}$ Ks. prof. C. Bartnik zastrzega jednak, że w odniesieniu do Kościoła należy mówić o „wspólnocie”, ale w „Jezusie Chrystusie”12.

Jak możemy zauważyć, panorama rozumienia pojęcia communio zasadniczo dzieli się na rozumienie naturalistyczne oraz sakralne. W podjętym zagadnieniu, które wskazuje na duchowy wymiar życia człowieka, interesuje nas przede wszystkim wymiar sakralny. Użycie określenia ,naturalistyczne” oznacza takie, które nie rozpatruje wspólnoty w kontekście nadprzyrodzonych relacji z Bogiem.

9 Por. R. Wroński, ,Trynitarne”, 57.

10 Por. C. Bartnik, Dogmatyka, t. II, 40.

11 Por. Kompendium Nauki Społecznej Kościoła, 96-98 (Społeczna natura człowieka); M. Tatar, „Wspólnotowy”, 114.

12 Por. C. Bartnik, Dogmatyka, t. II, 40. 
Oznacza to, że opisuje jedynie relacje człowieka o charakterze naturalistycznym, stanowiące przedmiot działań naukowo-badawczych takich dziedzin jak psychologia, socjologia, politologia. Mamy także do czynienia z badaniami, które zajmują się religijnością, ale ich charakter odbiega od teologii. Są to: etnologia, etnografia czy też historia kultury oraz kultur ${ }^{13}$.

$\mathrm{Na}$ gruncie eklezjologii bardzo znaczący w tym względzie i nie do pominięcia jest wkład wybitnego teologa Y. Congara ${ }^{14}$. Ten wielki „teolog laikatu” oraz bardzo otwarty ekumenista stwierdza, odnośnie do Kościoła, że jest to rzeczywistość „obcowania z bliźnim, komunikowania się z nim, oddawania się mu jako partner i pomocnik, z którym nawiązuje się dialog i współpraca, następnie współdzielenie się, a ostatecznie komunia"15.

$\mathrm{W}$ tę teologiczną panoramę prób określenia istoty i natury communio w odniesieniu do Kościoła wpisuje się kard. J. Ratzinger, którego śmiało możemy nazwać ,teologiem communio”. Przeprowadził on bardzo gruntowną analizę tego terminu, wskazując na jego potrójne znaczenie. W ten sposób nakreślił podstawy rozumienia ewangelicznego i teologicznego. Zauważa, że jego korzenie sięgają do rozumienia świeckiego. Podejmując próbę wyjaśnienia, konfrontuje je z piątym rozdziałem Ewangelii św. Łukasza. W kontekście powołania uczniów pada słowo opisujące relację pomiędzy Jakubem i Janem

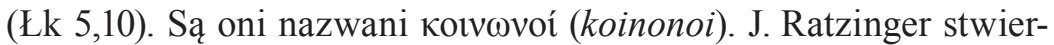
dza, że w języku niemieckim zostało przetłumaczone na Gefährte, tj. „towarzysz”, „wspólnik”"16. Sam jednak słusznie kwestionuje takie tłumaczenie, twierdząc, że nie jest ono adekwatne, ponieważ nie odzwierciedla właściwej rzeczywistości, jaka znajduje się pomiędzy nimi. Wspólnota zaistniała pomiędzy nimi ma charakter świecki i wynika z jednoczącego charakteru zajęcia, pracy, wspólnych wartości ${ }^{17}$. Możemy zatem zauważyć, że akcent dotyczący rozumienia

13 Por. M. Tatar, „Wspólnotowy”, 114.

14 Por. Y. Congar, Diversités et communion; T. Dzidek, Mistrzowie, 617.

15 Y. Congar, Lay People in the Church, 271.

16 J. Ratzinger, „Kościół - znak wśród narodów”, 291; R. Wroński, „Trynitarne”, 53.

17 Por. tamże; J. Ratzinger, Kościół. Pielgrzymująca wspólnota wiary, 64. 
tego terminu przenosi się z osób na rzeczywistość, która pomiędzy nimi istnieje.

Kolejny etap analizy prowadzi kardynała w kierunku korzeni żydowskich. Idąc za rozumieniem, które prezentuje A. Hauck, J. Ratzinger twierdzi, że odpowiednikiem communio jest hebr. chaburah, które oznacza relację wynikającą z przynależności do pewnej grupy oraz uczestnictwa w liturgii Paschy jako antycypacji tajemnicy. Ciągle jednak pozostajemy na poziomie relacji międzyludzkich, nie wychodząc w kierunku relacji człowieka do Boga. Ta ostatnia relacja związana jest z berith, czyli ,przymierzem”18.

Dla pełni obrazu analizy, idąc za myślą bawarskiego teologa, należy sięgnąć do korzeni greckich. Dochodzimy wówczas do wniosku, że na gruncie filozofii rozumienie tego słowa jest przeciwne mentalności hebrajskiej. O ile rozumienie hebrajskie nie łączyło go z relacją pomiędzy Bogiem i człowiekiem, zawężając do relacji ludzkich, o tyle grecka filozofia wprowadza je w kontekst religijny. J. Ratzinger, odwołując się do Platona, twierdzi: „Według niego komunia między bogami i ludźmi jest także przyczyną komunii międzyludzkiej"'19. Głównym akcentem nie jest jednak wspólnota, ale ,jedność”. Na tej podstawie dochodzimy do wniosku, że Nowy Testament bardzo wyraźnie wskazuje na charakter jedności (communio) pomiędzy człowiekiem i Bogiem w Jezusie Chrystusie, a także jedność w Nim z innymi ludźmi ${ }^{20}$.

Poszukiwanie właściwego rozumienia i analiza samego słowa, a także pojęcia communio, wzbogaca dokument, który nie może być w badaniach nad tym przedmiotem pominęty. Chodzi o List do Biskupów Kościoła katolickiego o niektórych aspektach Kościoła pojętego jako komunia Communionis notio, który został podpisany przez ówczesnego Prefekta Kongregacji Nauki Wiary kard. J. Ratzingera. Ten istotny dla eklezjologii oraz duchowości eklezjalnej dokument

18 Por. J. Ratzinger, „Kościół - znak wśród narodów”, 293; J. Ratzinger, Kościół. Pielgrzymująca wspólnota wiary, 66. Jak twierdzi Ratzinger: „Staremu Testamen-

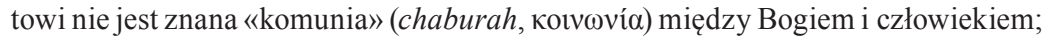
Nowy Testament jest tą komunią w osobie i przez osobę Jezusa Chrystusa". Por. R. Skrzypczak, „Kościół”, 175.

19 J. Ratzinger, „Kościół-znak wśród narodów”, 294. Por. R. Wroński, „Trynitarne”, 53.

20 Por. J. Ratzinger, „Kościół - znak wśród narodów”, 294. 
koncentruje swoją uwagę na pojęciu Kościoła jako komunii. Niemniej jednak obligatoryjne stało się klarowne i autorytatywne wyjaśnienie sposobu rozumienia communio w kategoriach teologicznych. Nawiązując do wymiaru trynitarnego, który jest prawzorem komunii, wskazuje na jedność ludzi w wierze, która przeżywana jest w doświadczeniu ziemskim i ukierunkowana ku pełni eschatologicznej, czyli pełni świętości ${ }^{21}$. Dokument ten również podkreśla problemy związane z precyzyjnym zaprezentowaniem znaczenia tego pojęcia i stwierdza, że jest ono niejednoznaczne. Z tego względu konieczne jest odniesienie do kontekstu biblijnego oraz patrystycznego. Z niego wynika podwójny wymiar, tj. wertykalny, który wskazuje na relację z Bogiem, oraz horyzontalny, dotyczący relacji z ludźmi² ${ }^{22}$. Jest to dość klasyczne ujęcie, które wydaje się w sposób bardzo prosty wyjaśniać podstawowy sposób rozumienia communio. Ze względu jednak na podjęcie tego zagadnienia w kontekście teologii duchowości, należy podkreślić, że to zasadnicze uporządkowanie ma kluczowe znaczenie, ponieważ wskazuje na właściwy kierunek rozumienia i rozwijania duchowości człowieka. Oznacza to, że nie można mówić o dynamice rozwoju duchowego, pomijając którykolwiek z tych wymiarów. Pominięcie wymiaru wertykalnego sprawia, że właściwie nie można mówić o duchowości komunijnej, ale całość egzystencji człowieka należy sprowadzić do poziomu naturalno-doczesnego życia społecznego, którym rządzą jedynie prawa stanowione przez człowieka. Z kolei pominięcie wymiaru horyzontalnego niesie ze sobą niebezpieczny spirytyzm wynikający z niewłaściwego rozumienia i przyjęcia objawienia. Skrzywiony obraz Boga rodzi deformację obrazu człowieka oraz otaczającej go rzeczywistości. W rezultacie religijność człowieka oraz rozwój wiary na tej drodze idą w kierunku bezdusznego formalizmu oraz laksyzmu.

Idąc za myślą dokumentu, należy podkreślić, że communio jest darem Boga i przejawem Jego inicjatywy, w której wychodząc ku człowiekowi, przede wszystkim to On buduje tę rzeczywistość poprzez

21 Por. Communionis notio 3; M. Jagodziński, „,Komunijno-trynitarna”, 12-15; W. Kućko, „Braterstwo”, 131; R. Skrzypczak, „Kościół”, 176.

22 Por. Communionis notio 3; K.-W. Niebuhr, „Biblisch-theologische”, 106. 
Jego słowo oraz sakramenty św. ${ }^{23}$ Opierając się na teologii dogmatycznej w tym względzie, zauważamy, że jest to niezwykle istotna koncepcja, która w sposób bezpośredni wskazuje na rzeczywistość oraz dynamikę rozwoju duchowego chrześcijanina.

Analiza ta jest niezwykle istotna z punktu widzenia podjętej problematyki duchowości eklezjalnej. Nie chodzi o opis skali hellenizacji chrześcijaństwa czy też ścisłości związku z korzeniami judaistycznymi, ale wskazanie na właściwy sposób rozumienia communio. Zyskujemy bardzo klarowny obraz świeckiego i socjalnego rozumienia, a także drogę transformacji tego pojęcia w chrześcijaństwie. W ten sposób odzwierciedla ono nie tylko wspólnotowość, ale przede wszystkim jedność, która ją tworzy, skupiona na osobie Jezusa Chrystusa, który jest Głową Kościoła. Na gruncie teologii duchowości, a także doświadczenia duchowego, ,jedność”, ,zjednoczenie" ma kluczowe znaczenie. Chodzi o naturę i charakter uświęcającego dążenia człowieka do zjednoczenia z Bogiem, czyli najgłębszą rzeczywistość tej relacji. Jedność z Bogiem rodzi życie we wspólnocie z Nim, a także rodzi jedność międzyludzką oraz wspólnotowość eklezjalną 24 . Można zatem stwierdzić, że zarówno jedność, jak również wspólnotowość są kompatybilne. Jedność prowadzi do wspólnotowości, zaś wspólnotowość buduje jedność. Z tego względu Kościół, z uwagi na swoją naturę, zobligowany jest przekraczać siebie.

${ }_{23}$ Por. Communionis notio 3; M. Jagodziński, Sakramenty, 319-408.

${ }^{24}$ S. Juan de la Cruz, Subida del Monte Carmelo, I, 11.2. Św. Jan od Krzyża rozumie to zjednoczenie w kategoriach wolitywnych: „Y la razón es porque el estado de esta divina unión consiste en tener del alma, según la volintad, co tal transformación en la voluntad de Dios, de manera que no Haya en ella cosa contraria a la voluntad de Dios, sino que todo y po $r$ todo su movimiento sea voluntad solamente de Dios”. Z kolei św. Teresa z Avila ujmuje je w następujący sposób: „Digamos que sea la unión, como si dos velas de cera se juntasen tan en extremo, que toda la luz fuese una, o que el pábilo y la luz y la cera es todo uno; mas después bien se puede apartar la una vela de la otra, y quedan en dos velas, o el pábilo de la cera. Acá es como si cayendo agua del cielo en un río o fuente, adonde queda hecho todo agua, que no podrán ya dividir ni apartar cual es el agua, del río, o lo que cayó del cielo; o como si un arroyico pequeño entra en la mar, no habrá remedio de apartarse; o como si en una pieza estuviesen dos ventanas por donde entrase gran luz; aunque entra dividida se hace todo una luz": S. Teresa, Castillo interior, VII, 2.4. 
Posłanniczo-misyjny charakter jego powołania musi uwzględniać również tych, którzy pozostają poza chrześcijaństwem ${ }^{25}$.

Poszukiwania naukowo-badawcze na gruncie teologii dotyczące właściwego znaczenia communio muszą odwoływać się do dziedzictwa chrześcijańskiego sięgającego do źródła, którym jest Pismo Święte oraz Tradycja Kościoła. Ks. prof. A. Czaja, idąc za Katolickim katechizmem dla dorosłych Niemieckiej Konferencji Biskupów, postuluje, aby w dążeniu do właściwego rozumienia communio przede wszystkim uwzględnić „współudział (participatio) ludzi w tzw. rzeczach świętych ofiarowanych przez Boga"26. Należy stwierdzić, że teolog wypowiada to twierdzenie w kontekście communio sanctorum. Takie ujęcie jest w pełni uzasadnione. Jednakże, jeśli bierzemy pod uwage rozumienie communio samo w sobie, to należy poddać pod refleksję relacje pomiędzy „,zjednoczeniem” a „uczestnictwem”. W perspektywie teologicznej, a zwłaszcza teologii duchowości, ten porządek jest niezwykle istotny ${ }^{27}$. Biorąc pod uwagę zasadniczą kwestię, którą jest dążenie Boga do zjednoczenia z człowiekiem, wynikające ze stworzenia, Wcielenia, Odkupienia, a także ostatecznej rekapitulacji o charakterze eschatologicznym, należy w porządku działania człowieka uznać pierwszeństwo dążenia do tegoż zjednoczenia. Udział człowieka w dobrach Boga i rozwój jedności z Nim, opierający się na Jego samoudzieleniu, jest owocem Jego inicjatywy. Dążenie zaś człowieka do pełni zjednoczenia człowieka z Bogiem powoduje i rozwija udział w Jego życiu.

\section{Komunijna duchowość starotestamentalna}

Zagadnienie eklezjalnej duchowości komunijnej stawia nas przed problemem dotyczącym zasadniczych jej źródeł. Analiza tejże duchowości domaga się sięgnięcia do objawienia Starego Testamentu i podkreślenia szczególnych momentów, które wskazują komunijny charakter działania Boga, doprowadzający do ostatecznego Przymierza, którym jest Jezus Chrystus. Jak stwierdza kard. J. Rartzinger,

25 Por. R. Wroński, „Trynitarne”, 67.

26 A. Czaja, ,Communio w eklezjologii”, 113.

27 Por. M. Tatar, „Wspólnotowy”, 115. 


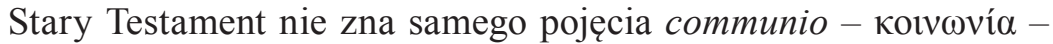
chaburah. Wynikało to z progu transcendencji Boga, który był dla człowieka nieprzekraczalny. $Z$ tego względu kluczowe znaczenie miało ,przymierze”, podkreślające suwerenność Boga i jednocześnie Jego absolutną nadrzędność w stosunku do człowieka ${ }^{28}$. Ten element bardzo wyraźnie akcentuje św. Paweł, stwierdzając: „W Nim bowiem

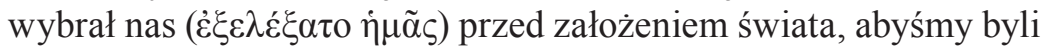
święci i nieskalani przed Jego obliczem" (Ef 1,4). Dlatego należy zaznaczyć, że człowiek stworzony przez Boga jest ukierunkowany na pełnię jedności z Nim, pozostając w komunii z drugim człowiekiem (por. Rdz 3,8; 1,27-28; 2,18) ${ }^{29}$. Określamy ten stan jako ontyczne powołanie do świętości i - jak zauważamy - posiada on charakter wybitnie komunijny. Na przeszkodzie realizacji tego powołania stanął grzech (por. Rdz 3,6-7), który już na samym początku doprowadził do dysharmonii i rozbicia ontyczno-miłosnej jedności (por. Rdz 3,8-13). Jego podstawą jest pycha, posiadająca źródło w osobowym złu (por. Rdz 3,4-5), prowadząca do nienawiści (por. Rdz 4,8; 6,11 ) oraz nieustannie powstających podziałów (por. Rdz 11,1-9). Jak wynika z przekazu biblijnego, już w tym miejscu rozpoczyna się proces, w którym Bóg dąży do odzyskania możliwości komunijnego bycia z człowiekiem, a także komunijnego rozwoju człowieka jako istoty wspólnotowej. Tak należy odczytać i uznać tzw. „tekst protoewangelii” (por. Rdz 3,15), a następnie teologię „,nowego Adama”, przywracającego komunię człowieka z Bogiem, a także z bliźnim, którą prezentuje św. Paweł (por. 1 Kor 14,45; Kol 3,10; 2 Kor 5,17n; Ga 6,15; Rz 5,12-21; Ef 2,15-18). Z pewnością tekst ,,protoewangelii” jest momentem kluczowym w relacji Boga do człowieka, do którego nawiązuje Katechizm Kościoła Katolickiego w kontekście genezy Kościoła: „Zwołanie ludu Bożego zaczyna się w chwili, w której grzech niszczy jedność ludzi z Bogiem oraz komunię ludzi między sobą"30.

28 Por. J. Ratzinger, Kościót. Pielgrzymująca wspólnota wiary, 65-66; R. Skrzypczak, „Kościół”, 175; R. Wroński, „Trynitarne”, 53.

29 Por. F. Mickiewicz, ,Objawienie”, 26.

30 KKK 761. 
Analiza szczególnych momentów w dziejach narodu wybranego wskazuje na historiozbawczo-uświęcający proces rozwoju communio Boga z człowiekiem, który jest jednocześnie przygotowaniem do pełni, która urzeczywistni się w osobie Jezusa Chrystusa. Kolejnym wydarzeniem wskazującym na rozwój tego procesu jest przymierze - berit, oznaczające układ dwustronny, zawierający nierówność w podziale obowiązków. W Septuagincie oddano to jako greckie

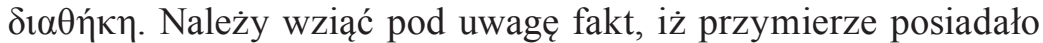
w Starym Testamencie bardzo szerokie zastosowanie społeczne. Za-

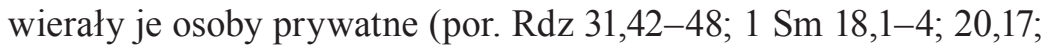
23,18), było narzędziem budowania relacji narodów (por. $1 \mathrm{Krl} 5,26$; 15,19), zawierały je jednostki z grupami (por. Rdz 21,22-33; 26,28; $2 \mathrm{Krl} \mathrm{11,4-8),} \mathrm{istniało} \mathrm{między} \mathrm{grupami} \mathrm{(por.} \mathrm{Joz} \mathrm{9,3-27).} \mathrm{W} \mathrm{takich}$ kategoriach rozumiano także małżeństwo (por. Ml 2,14). Kluczowym i charakterystycznym wymiarem dla Starego Testamentu jest przede wszystkim charakter i znaczenie przymierza zawieranego pomiędzy Bogiem a człowiekiem. Już na wstępie należy zaznaczyć, że Inicjatorem jest Bóg, który wkraczając w historię człowieka, ustanawia z nim przymierze, tzn. wchodzi w jego życie. Jak zaznacza ks. prof. T. Jelonek, jako model religii, zostało wprowadzone przez Mojżesza (Wj 19,1-6) ${ }^{31}$. Warto także podkreślić inne jego elementy, które określały relację Boga do wybranego narodu: jest związane z doświadczeniem jego przekazu (por. Rdz 9,8-17), ma charakter uniwersalistyczny (por. Syr 44,18), jest drogą powrotu do jedności z Bogiem - to przymierze z Abrahamem (por. Rdz 9,1-5; 15,7-21; 17,1-14), przyjmuje formę Prawa - przymierze synajskie (por. Wj 3,7-10; 19,4-6; 20,1-17), posiada związek z ofiarą i kultem (por. Wj 24,4-8), miało swoje widzialne znaki w postaci święta Paschy, arki przymierza (por. Wj 37,1-9). Kolejne przymierza zawarte zostały z pokoleniem Lewiego i dotyczą stanu kapłańskiego (por. Lb 25,10-13) oraz z Dawidem i związane są z teokracją (por. 2 Sm 7,8-16; Syr 45,23n). Nie mogą być jednak traktowane jedynie w kategoriach prawnych czy też układu społeczno-moralnego. Właściwie mamy do czynienia z doświadczeniem wskazującym na znacznie głębszą rzeczywistość pomiędzy Bogiem a wybranym przez Niego ludem. Pomimo słabości

31 Por. T. Jelonek, Teologia, 288; F. Mickiewicz, „Objawienie”, 28. 
człowieka i narodu, który zrywał to przymierze, Bóg pozostawał w swojej miłości dyspozycyjny ze swoim przebaczeniem i gotowością zawierania nowego przymierza. Ta miłosna dyspozycyjność Boga jest charakterystyczną cechą zjednoczenia. Bóg jest Pasterzem (por. Ez 34), ale także Ojcem (por. Iz 64,7; Ml 2,10). Jego relacja przyjmuje charakter porównywalny ze związkiem małżeńskim jako Oblubieńca wobec oblubienicy (por. Oz 1-3; Iz 54,4-14; 61,10; 62,4n; Jr 2,2; Ez 16,5-15.22). Z tego względu zawarte przymierze, które materialnie zostało umieszczone na kamiennych tablicach, znajduje swoje odzwierciedlenie w głębi człowieczeństwa (por. Jr 31,31-34). Ta zapowiedź wskazuje na nieustanne działanie Boga (por. Ez 16,60.62) i dąży do właściwego zrozumienia konieczności metanoi zarówno samego człowieka, jak również świata (por. Ez 36,26-38). Nowe przymierze o charakterze uniwersalistycznym, które ma swój początek w przymierzu z Abrahamem i Noem, znalazło swoje spełnienie w Słudze Jahwe (por. Iz 42,6; 49,6; Ga 3,16).

Analizując Stary Testament, można wskazać na pewne idee i figury, będące prototypem Kościoła, świadczące o komunijnej relacji z Bogiem. Wśród nich należy wymienić określenie „,naród wybrany”

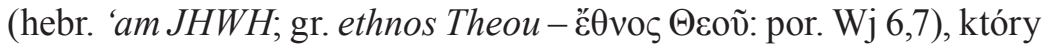

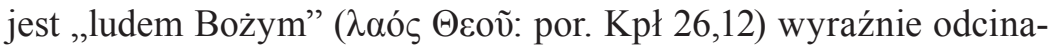
jącym się od gojim, ethne - niezwiązanym z Jahwe. Łączy się ono w sposób bezpośredni z określeniem narodu jako „własności Boga”

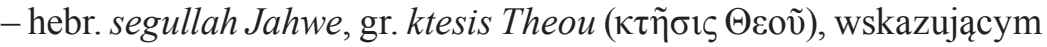
na charakter jedności z Bogiem (por. Wj 19,5; Ps 135; Iz 5,1-7). Równie istotnym modelem i figurą jest określenie „dwanaście pokoleń” (Wj 24,4; 28,21), jako pewna rekapitulacja Boskiej ikony wszystkich narodów. W Nowym Testamencie znalazła ona urzeczywistnienie w powołaniu „Dwunastu” (por. Mk 3,13-19; Łk 6,12-19), którzy są u początków Kościoła. Kolejny model to „święta Reszta” - hebr. szear/szeir, gr. leimma ( $\lambda \varepsilon \tilde{i} \mu \mu \alpha$ : por. Iz 1,8-9; 4,2-6; 7,3; Am 8,1-3). Wskazuje on na charakter związku Boga z małą i wybraną częścią, która jest odzwierciedleniem tych wiernych, którzy zachowali przymierze zagrożone w czasie apostazji. Istotne znaczenie posiada figura

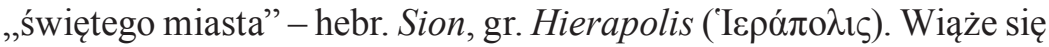
ona z bardzo konkretną lokalizacją dotyczącą Syjonu, Jeruzalem lub samą świątynią jerozolimską (por. Wj 15,1-18; Ps 78; 79; 87; Iz 2,2; 
27,13; 60,1-9). Jest to centralne miejsce królowania Boga i Mesjasza, sama chluba Izraela, to miejsce spotkania nieba z ziemią, znak raju, życia, a także odcięcia się od zła. Równie istotnym określeniem, które przywołuje ks. prof. C. Bartnik, jest „diaspora” - hebr. gola/galut. Dotyczy oderwania od ojczyzny. Wprost wskazuje na czas Izraela będącego w niewoli, niewchodzącego w relacje z innymi narodami, oczekującego wyzwolenia i spełnienia się obietnic Boga (por. Pwt 26,5n; 28,64n). Nawiązuje do tej idei św. Paweł, wskazując na wymiar eschatologiczny Kościoła (por. Flp 3,20). Kolejne określenie opisuje komunijne zebranie kultyczne, które w centrum posiada Boga, którego słucha i oddaje Mu cześć w określonych formach kultu. Jest to figura Izraela jako „zgromadzenia kultycznego" - hebr. 'edah/kahal,

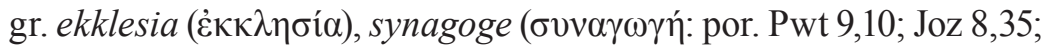
$\mathrm{Sdz} 20,2 ; 1 \mathrm{Krn}$ 28,8). Pośród bardzo istotnych figur znajduje się także ta, którą określa się jako „Królestwo Boże” - hebr. malkut JHWH, gr.

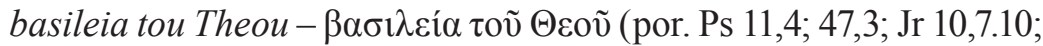
Iz 2,2-3). Królestwo to można ująć dwustopniowo, tj. królowanie samego Boga, będącego ponad wszystkim, oraz społeczność, w której panuje porządek wynikający z posłuszeństwa Bogu ${ }^{32}$.

Bez wątpienia możemy mówić o duchowości komunijnej Starego Testamentu. Posiada ona swoją specyfikę. Znajduje swoje odzwierciedlenie w odbiorze słów i dzieł Boga. Jak wskazuje A. Fanuli, jest to duchowość głęboko zakorzeniona w historii, jednocześnie bardzo mocno związana z treścią słowa, które Bóg przekazuje konkretnemu narodowi ${ }^{33}$. Słowo będące odzwierciedleniem Boga urzeczywistnia się, jak twierdzi o. prof. H. Langkammer, na płaszczyźnie historycznej oraz teologicznej. Bóg, który jest jedynym świętym w całej swojej istocie oraz pełni, wkracza w sposób zbawczy w historię człowieka. Wyprowadził go z podwójnej niewoli, tzn. polityczno-narodowej, ale jednocześnie niewoli duchowej narzuconej poprzez Prawo (por. Ga 5,18).

32 Por. C. Bartnik, Dogmatyka, t. II, 9-10.

33 Por. A. Fanuli, „Wprowadzenie”; M. Morwood, Tomorrow's Catholic, 44-52; F. Mickiewicz, „Objawienie”, 27. 


\section{Ratzingerowskie ujęcie relacji Starego Testamentu do Nowego w kontekście duchowości communio}

Sobór Watykański II, nawiązując do Soboru Watykańskiego I i Konstytucji Dei Filius (3), stwierdza, że objawienie się Boga ma nie tylko charakter informacyjny, ale przede wszystkim formacyjny. Prowadzi ono do uczestnictwa w rzeczywistości, która przewyższa poznanie rozumowe ${ }^{34}$. W tym kontekście papież Benedykt XVI w posynodalnej adhortacji apostolskiej stwierdza, że objawienie posiadające charakter komunijny dokonuje się $\mathrm{w}$ miłosnym dialogu trynitarnym, do którego człowiek jest zaproszony. To wyznacza kierunek powołania człowieka $^{35}$. Charakter komunijnej duchowości starotestamentalnej ujawnia się także w podkreśleniu znaczenia powołania. Ten problem stał się przedmiotem analizy ks. prof. J. Kudasiewicza. Wskazując na starotestamentalne powołanie zarówno całego narodu, jak również poszczególnych osób, stwierdza, że właśnie ono wyznacza właściwy cel i charakter komunijnego bycia Boga z człowiekiem. Charakterystycznymi etapami realizacji powołania są, jak twierdzi teolog, nawiązując do nauki Soboru Watykańskiego II $^{36}$ : wybór narodu, w którym zwiera się powołanie, zawarcie przymierza, które potwierdza je, oraz zapowiedź Nowego Przymierza ${ }^{37}$.

Zasadniczy problem dotyczy relacji Starego Testamentu do Nowego Testamentu. Przytoczone figury i modele mają charakter zapowiadający, ale to nie wyjaśnia w pełni problemu. Nie można objawienia starotestamentalnego zawężać jedynie do symboliki, zapowiedzi czy też figury, ponieważ mamy do czynienia z bardzo konkretnym komunijno-uświęcającym działaniem Boga wobec wybranej i określonej przez Niego społeczności ludu. Jest to zatem rzeczywistość, która jest uchwytna i możliwa do określenia i interpretacji w kategoriach komunijno-duchowych. Kluczowe dla poruszanego

34 Sobór naucza w następujących słowach: „Przez objawienie Boże zechciał Bóg ujawnić i oznajmić siebie samego i odwieczne postanowienia swej woli o zbawieniu ludzi «dla uczestnictwa mianowicie w darach Bożych, które przewyższają całkowicie poznanie rozumu ludzkiego»": KO 6.

35 Por. Benedykt XVI, Verbum Domini 6; R. Wroński, „Trynitarne”, 49-50;

K.-W. Niebuhr, „Biblisch-theologische”, 106.

36 Por. KK 9.

37 Por. J. Kudasiewicz, Powołanie, 55. 
zagadnienia są słowa zawarte w Liście do Hebrajczyków: „Wielokrotnie i na różne sposoby przemawiał niegdyś Bóg do ojców [naszych] przez proroków, a w tych ostatecznych dniach przemówił do nas przez Syna" (Hbr 1,1). Istotne wyrażenie, wskazujące na pewną

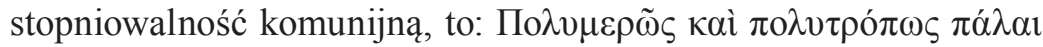

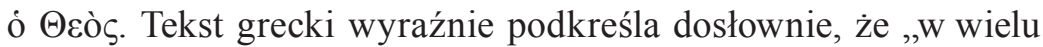
częściach", które należy rozumieć jako stopniowość, ale także i na

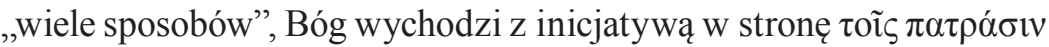
(„,o ojców”). Znajdujemy także uogólniające wskazanie narzędzia: $\pi \rho о \varphi \eta ́ \tau \alpha \iota \varsigma$.

Katechizm Kościoła Katolickiego, odnosząc się do komunijnego działania Boga w Starym Testamencie, dokonuje syntezy, podkreślając jego dwuaspektowość, tj. ,wybranie narodu” oraz nieustanne odnawianie „przymierza”, któremu Izrael się sprzeniewierzał, zachowując się jak ,nierządnica"38.

W analizie tego zagadnienia niezwykle istotna jest prezentacja Ratzingerowskiego sposobu odczytywania Starego Testamentu w kontekście teorii civitas Dei. Idąc za św. Augustynem, twierdzi, że ,państwo starotestamentowe stanowi portio impiae civitas" ${ }^{39}$, który przynależy do świata doczesnego. Jednocześnie to civitas pozostaje w jedności z Bogiem i odsłania Jego wspólnototwórcze działania. Teocentryzm Starego Testamentu jest kluczem do właściwego zrozumienia jego duchowości, która rozumiana jest jako przekaz nakazów, przekazywanie poleceń przez ludzi do tego wybranych. W dużej mierze koncentruje się na kulcie oraz posłuszeństwie. Ten element w teologii starotestamentalnej św. Augustyna znajduje odzwierciedlenie w określeniu szczęścia Żydów ograniczającego się do beatitudo terrena ${ }^{40}$. Całość tej analizy doprowadza kard. J. Ratzingera do stwierdzenia, że św. Augustyn, patrząc na Stary Testament, wyróżnia trzy rodzaje tekstów: a) dotyczące ziemskiego Jeruzalem; b) dotyczące niebieskiego Jeruzalem - mające sens duchowy; c) odnoszące się dosłownie do jednego i drugiego, ale przyjmujące

38 Por. KKK 762.

39 J. Ratzinger, „Lud i Dom Boży”, 365.

40 Cyt. za J. Ratzinger, „Lud i Dom Boży”, 366. 
charakter mistyczny ${ }^{41}$. Na szczególne podkreślenie zasługuje ostatnia kategoria, ponieważ wskazuje w sposób bezpośredni na charakter odczytywania rzeczywistości communio w Starym Testamencie. Jest to teofaniczno-teocentryczna duchowość, która wskazuje na dojrzewanie do „niebieskiego Jeruzalem”, tzn. na proces życia duchowego. Zupełnie odrębnym zagadnieniem są charakter i środki tego procesu. Interesuje nas przede wszystkim podkreślenie prawdy o jedności człowieka z Bogiem w przestrzeni starotestamentalnej. Wskazuje na to samo określenie populus Dei. Teologia Starego Testamentu koncentrująca się na idei ,przymierza” podkreśla, że mamy do czy-

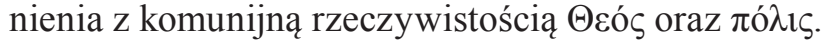

Kard. J. Ratzinger, zajmując się eklezjologią w kontekście Starego Testamentu, jako dogmatyk, odwołuje się do Tertuliana, wskazując, że Kościół zajmuje miejsce Synagogi i staje się ,prawdziwym Izraelem"42. Podkreśla w tym względzie konieczność zwrócenia uwagi na dualizm postrzegania Testamentów przez Marcjona, który przyporządkowywał Bogu Ojcu Stary Testament zaś Jezusowi Chrystusowi Nowy Testament ${ }^{43}$. To wskazywałoby na podwójną drogę jednoczenia się Boga z człowiekiem. Należy stwierdzić, że mamy do czynienia $\mathrm{z}$ takim porządkiem historiozbawczym w historii człowieka. Bóg zaś jest niezmienny w swojej jednoczącej miłości. Dlatego kard. J. Ratzinger wskazuje, za Tertulianem, że jedność Testamentów nie wynika z jedności litery, ale ducha. Bardzo cennym dorobkiem w tym względzie jest rozprawa kardynała dotycząca Kościoła w nauczaniu św. Augustyna. Na podstawie jego analizy Starego Testamentu w relacji do Nowego, w oparciu o dzieła św. Augustyna, zauważamy właściwe znaczenie tego pierwszego dla sposobu bycia w communio Boga z Izraelem. Posłanniczo-misyjny charakter narodu wybranego rzutuje także na sposób rozumienia jego bycia pomiędzy Bogiem a światem. Idąc za biskupem z Hippony, J. Ratzinger zauważa, że właściwe odczytanie Starego Testamentu może dokonywać się w świetle tajemnicy Wcielenia ${ }^{44}$. Uważa, że

\footnotetext{
41 Por. tamże, 367.

42 Tamże, 135-136.

43 Por. tamże.

44 Por. J. Ratzinger, „Lud i Dom Boży”, 360; M. Mejzner, „Lektura patrystyczna”, 42.
} 
w ten sposób odpowiada św. Augustyn na bardzo istotne pytanie dotyczące zbawienia poza Kościołem. Twierdzi, że Stary Testament jest wobec Nowego jak obraz do rzeczy czy też cień do ciała ${ }^{45}$. Na tej podstawie wyciąga wniosek, że Nowy Testament stanowi treść poznawczą dla Starego i jest jego intelektem. Idąc dalej w swojej analizie „Doktora łaski”, stwierdza, że należy odejść od czasowego rozpatrywania tejże relacji. W ten sposób dochodzi do bardzo istotnego wniosku wynikającego $\mathrm{z}$ analizy poruszanego zagadnienia i odsłaniającego homo vetus, który jest jednocześnie homo exterior, oraz homo novus równoznacznego z homo interior. Możemy zatem mówić o różnicy sposobu bycia człowieka wobec Boga nie zaś różnicy czasów ${ }^{46}$. Z pewnością ten aspekt jest bardzo istotny i w pewien sposób podkreśla charakter rozumienia dychotomii testamentalnej. Wydaje się jednak, że jest to uproszczenie. Należy podkreślić jakościową przemianę charakteru komunijnego działania Boga wobec człowieka, która dokonała się w tajemnicy Wcielenia. Z tego względu ograniczenie charakteru człowieka do vetus, będącym jednocześnie exterior, nie jest do końca prawdziwe.

Prawda objawiona dokonuje transformacji w postrzeganiu relacji Starego do Nowego Testamentu. Nauka Kościoła, powołując się na św. Augustyna, podkreśla, że „Nowy Testament był ukryty w Starym, a Stary w Nowym znalazł wyjaśnienie"47.

\section{Nowa jakość communio w Jezusie Chrystusie}

Nowy Testament odsłania istotowy zwrot w komunijnej relacji Boga i człowieka. Wskazują na ten fakt następujące słowa Jezusa Chrystusa: „Tak bowiem Bóg umiłował świat, że Syna swego Jednorodzonego dał, aby każdy, kto w Niego wierzy, nie zginął, ale miał życie wieczne. Albowiem Bóg nie posłał swego Syna na świat po to, aby świat potępił, ale po to, by świat został przez Niego zbawiony" (J 3,16-17). Należy zatem, mówiąc o duchowości komunijnej w odniesieniu do Nowego Testamentu, wziąć pod uwagę całość życia

45 Por. Św. Augustyn, De civitate Dei, XV, 2; In Ev. Joh., 11, 8 (PL 35, 1979).

46 Por. J. Ratzinger, „Lud i Dom Boży”, 363.

$47 \mathrm{KO} 16$. 
Jezusa Chrystusa, tj. słowa czyny, gesty, znaki, cuda i postawy, Jego śmierć, Zmartwychwstanie oraz Zesłanie Ducha Świętego ${ }^{48}$. Cały Nowy Testament możemy określić jako komunijne zjednoczenie Boga z człowiekiem w Jego Synu Jezusie Chrystusie. Jest to nowa jakość zjednoczenia uświęcającego, która w Nim się dokonała. Nauka Kościoła, uzasadniając tę tezę, opiera się na J 1,14; 6,68; Ga 4,4, konkludując, że: „Słowo Boże, które jest mocą Bożą ku zbawieniu każdego wierzącego (por. Rz 1,16), w pismach Nowego Testamentu znamienitym sposobem jest uobecnione i okazuje swą siłę"49. Idąc za tą myślą i powołując się na słowa Listu do Hebrajczyków $(1,1)$, Katechizm Kościoła Katolickiego zauważa, że Jezus Chrystus jest „jedynym, doskonałym i ostatecznym Słowem Ojca" ${ }^{50}$. Ten komunijny realizm widoczny jest jeszcze bardziej w punkcie 103, w którym Kościół, idąc za nauką Soboru Watykańskiego II, stwierdza: „Z tego powodu Kościół zawsze czcił Pismo święte, podobnie jak czci Ciało Pana. Nie przestaje ukazywać wiernym Chleba życia branego ze stołu Słowa Bożego i Ciała Chrystusa”. Znamienne jest to, że dokument powołuje się także na klasyka mistyki hiszpańskiej św. Jana od Krzyża, podkreślając nową i ostateczną jakość objawienia, przełomową dla życia, rozwoju człowieka, Kościoła, a także ich ostatecznego celu ${ }^{51}$.

48 Ten bardzo istotny element Kościół w swoim nauczaniu określa następująco: „Jezus Chrystus więc, Słowo Wcielone, «człowiek do ludzi» posłany, «głosi słowa Boże» (por. J 3,34) i dopełnia dzieła zbawienia, które Ojciec powierzył Mu do wykonania (por. J 5,36, 17,4). Dlatego Ten, którego gdy ktoś widzi, widzi też i Ojca (por. J 14,9), przez całą swoją obecność i okazanie się przez słowa i czyny, przez znaki i cuda, zwłaszcza zaś przez śmierć swoją i pełne chwały zmartwychwstanie, a wreszcie przez zesłanie Ducha prawdy, objawienie doprowadził do końca i do doskonałości oraz świadectwem bożym potwierdza, że Bóg jest z nami, by nas z mroków grzechu i śmierci wybawić i wskrzesić do życia wiecznego": KO 4. Por. F. Mickiewicz, „Objawienie”, 29.

$49 \mathrm{KO} 17$.

50 KKK 65; 102. W tym drugim punkcie Katechizm stwierdza: „Przez wszystkie słowa Pisma świętego Bóg wypowiada tylko jedno Słowo, swoje jedyne Słowo, w którym wypowiada się cały”. Por. tamże, 124; F. Mickiewicz, „Objawienie”, 29.

51 Por. KKK 65. Św. Jan od Krzyża stwierdza: „Porque en darnos, como nos dio a su Hijo, que es una Palabra suya, que no tiene otra, todo nos lo habló junto y de una vez en esta sola Palabra, y no tiene más que hablar": S. Juan De la Cruz, Subida, II, 22, 3. 
Sięgając do okresu wczesnopatrystycznego, który ma ogromne znaczenie dla właściwego uchwycenia istoty Nowego Testamentu, zauważamy, że ojcowie i pisarze wczesnochrześcijańscy bardzo chętnie nawiązują do Starego Testamentu, ale postrzegany jest on w ścisłej relacji do Nowego Testamentu. Ks. M. Mejzner stwierdza w swojej analizie, że ,skoro Jezus Chrystus jest wcielonym Słowem Bożym, to nie tylko starotestamentowe proroctwa i figury, ale wszystkie pisma natchnione są na Niego ukierunkowane" 52 . Odwołując się do Listu Klemensa do Rzymian, Listu Pseudo-Barnaby, św. Justyna, św. Ireneusza, Orygenesa, wykazuje, że Nowy Testament jest tym wydarzeniem, które odsłania bezpośrednie i uniwersalistyczne communio Boga z człowiekiem w Jezusie Chrystusie ${ }^{53}$.

Komunikacyjno-komunijne wejście Boga w historię człowieka osiągnęło swoją pełnię w tajemnicy Wcielenia. Z tego względu tajemnica ta odgrywa niezmiernie istotną rolę w wykazaniu nowej jakości Nowego Testamentu. Ks. prof. F. Mickiewicz, powołując się na encyklikę Piusa XII Divino afflante Spiritu oraz myśl teologiczno-biblijną, którą prezentuje L. Alonso Schökel, zauważa, że Jezus Chrystus, przyjmując w pełni naturę ludzką, w pełni także staje się komunikatywny dla człowieka. W ten sposób powstaje nowa relacja pomiędzy Bogiem a człowiekiem na drodze objawienia, które staje się czytelne i rozpoznawalne ${ }^{54}$. To stwierdzenie współbrzmi $\mathrm{z}$ analizą B. Fortego, który - szczególnie opierając się na słowach ewangelicznych J 1,14 - zauważa, że Jezus Chrystus jest ,Słowem, które wyszło z Milczenia"55. W jego teologicznym ujęciu spotykamy pojęcie Boga jako „Milczącego”. Opierając się na słowach ewangelicznych (por. J 12,44-45), stwierdził, że ze stanu „Milczenia” wypowiedział Bóg Słowo, przez które nakreślił ostateczne powołanie świata i człowieka skierowane definitywnie ku doświadczeniu Milczenia. W ten sposób Słowo pochodzące od Milczącego weszło

52 Por. M. Mejzner, „Lektura patrystyczna”, 40.

53 Por. tamże, 42-53; V. Grossi, „Duchowość”, 330-344.

54 Por. F. Mickiewicz, „Objawienie”, 30-31; K.-W. Niebuhr, ,Biblisch-theologische", 106.

55 B. Forte, Istota, 55. Autor nawiązuje do stwierdzenia św. Ignacego Antiocheńskiego „Chrystus jest Słowem Boga, które wyszło z milczenia, z ukrycia i przyszło do nas": Św. Ignacy Antiocheński, Do Kościoła w Magnezji, 8,2. 
w bezpośrednie zjednoczenie z człowiekiem oraz jego naturą. Jednocześnie stworzony człowiek na „obraz” (Rdz 1,27) w Nim doświadcza pełni Boga ${ }^{56}$, a tym samym na nowo rozpoznaje swoją istotę. Analiza tego wymiaru historiozbawczego prowadzi do stwierdzenia, że jest to nieustanny proces komunikacyjno-uświęcający w działaniu Boga, urzeczywistniający się w całej wielowymiarowej przestrzeni istnienia świata ${ }^{57}$. Ta personifikacja zawarta $\mathrm{w}$ określeniu „Milczenie” i jednocześnie uosobione „Słowo”, które z niego wychodzi, by światu odsłonić uświęcającą prawdę, wydają się nielogiczne. Jest to jednak nielogiczność pozorna. Milczenie w tym wypadku nie oznacza niebytu czy nieistnienia, czy jakiejkolwiek pustki. Opisuje ono charakter objawienia. Bóg objawia siebie także poprzez milczenie, by człowiek mógł rozpoznać Słowo. Z punktu widzenia communio Boga z człowiekiem każdego czasu oraz każdej epoki, doświadcza człowiek adekwatności tegoż „Słowa”. Samoobjawienie Jezusa Chrystusa w tajemnicy Wcielenia odsłania bardzo istotną komunikacyjno-komunijną prawdę, że Bóg, identyfikując się z człowiekiem, jak to zostało stwierdzone, jednocześnie przekracza jego naturalne granice. Oznacza to, że prawda objawiona nie sprzeciwia się stworzonej przez Boga naturze człowieka, ale pozwala jej wychodzić poza własne ograniczenia. Benedykt XVI zauważa w tym kontekście, że właściwe odczytanie nowej jakości objawienia nowotestamentalnego domaga się właściwego zrozumienia Prologu św. Jana. Nie można poprzestać na przyjęciu faktu przemówienia Boga do człowieka w Słowie. Stwierdza, że konieczne jest nawiązanie do „początku” (por. Rdz 1,1), jego zdaniem wskazuje to na wewnętrzne życie Boga. Oznacza to, że Logos, który przekracza ramy czasu, odsłania ,po-

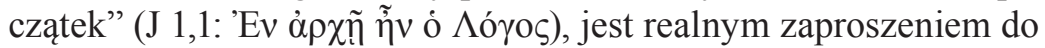
życia wewnątrz Boga, czyli w centrum miłosnej relacji ${ }^{58}$. To sprawia, że należy postrzegać Słowo Boże w kategoriach kosmicznych. Jest racją pierwszego stworzenia, ale jednocześnie kształtowania ,nowego człowieka", jak twierdzi Benedykt XVI, idąc za św. Bonawenturą ${ }^{59}$.

\footnotetext{
56 Por. M. Tatar, „Słowo Boże”, 177-180.

57 Por. K.-W. Niebuhr, „Biblisch-theologische”, 106; M. Jagodziński, Sakramenty, 48.

58 Por. VD 6.

59 Por. tamże, 8.
} 
To zjednoczenie komunijne człowieka $\mathrm{z}$ Bogiem dokonuje się w Kościele poprzez słowo oraz sakrament. Właśnie połączenie wypowiedzianego przez Boga „Słowa”, a także realne uobecnienie w Eucharystii tworzy nierozerwalną jedność. Nie można rozdzielić tych dwóch rzeczywistości. W ten sposób communio jest „Nowym Przymierzem" zawartym i zawieranym w osobie Jezusa Chrystusa. Misterium ,łamania chleba" wraz z „trwaniem w nauce Apostołów” (Dz 2,42) znajduje się w centrum wydarzeń nowotestamentalnych i jednocześnie z polecenia Jezusa Chrystusa konstytuuje Kościół jako miejsce i czas dążenia do zjednoczenia z Bogiem. Kard. J. Ratzinger wskazuje na prawne, sakralne oraz praktyczne treści tak doświadczanego i rozwijanego communio. Rzeczywistości tej doświadcza Kościół od samego początku, na co wskazują zarówno Ewangelie, jak również Listy Apostołów ${ }^{60}$.

Istotny wkład w rozwój komunijnej myśli nowotestamentalnej posiada R. Fabris. Podejmując próbę usystematyzowania tejże duchowości, wyróżnia następujące jej charakterystyczne rysy: a) jest duchowością religijną, ponieważ koncentruje się na wspólnotowym doświadczeniu religijnym, które przeniknięte jest obecnością Ducha Świętego jako głównego Autora rozwoju duchowego; b) jest duchowością eklezjalną - cecha ta to duchowość communio o charakterze trynitarnym, będącym wzorem i zarazem celem Kościoła opartego na wspólnocie wiary, sakramentów, charyzmatów oraz posłannictwa; c) to duchowość inkulturacyjna - oznacza to fakt uniwersalizmu duchowości ewangelicznej. Jak zaznacza, nie jest duchowością abstrakcyjną i czysto spekulatywną, ale posiada niezwykle realne i praktyczne zakorzenienie w procesie przemiany świata. To rzeczywiste i bardzo realistyczne wkroczenie Boga w historię człowieka każdego czasu, epoki, kultury i mentalności. Z tego względu Kościół, głosząc Ewangelię i sprawując sakramenty św., przenika wszystkie dziedziny i wymiary życia ludzkiego, stając się miejscem komunijnego spotkania i doświadczania Boga ${ }^{61}$.

Jezus Chrystus, będąc centralnym wydarzeniem historiozbawczym i jednocześnie komunikacyjno-komunijnym, pozwala człowiekowi

60 Por. J. Ratzinger, Kościót. Pielgrzymująca wspólnota wiary, 58-61.

61 Por. R. Fabris, „Wprowadzenie”, 12-14. 
odkrywać prawdę o Bogu i o sobie (por. J 14,1-14; Kol 1,15-20). W ten sposób wierzący odczytuje swoje miejsce w Kościele, odkrywa swoje eklezjalne powołanie, w które wpisuje się powołanie osobiste do świętości. Z tego względu rolą i miejscem Kościoła jest bycie „,niejako sakramentem ${ }^{62}$ " w życiu chrześcijanina. Chrystus jako jego Głowa jednocześnie jest jedynym i najwyższym Pośrednikiem (por. Hbr 7,24-28; 1 Tm 2,5-6), Sługą Jahwe przelewającym krew oraz żertwą i barankiem ofiarnym (por. Mk 14,24; Ef 1,7; J 1,36; 1 Kor 5,7; 1 P 1,18-19), ofiarą przebłagalną (por. 1 J 2,2), którą złożył za ludzkość oraz za jej grzechy (por. Łk 22,19; Mk 10,45; Ga 1,4; 1 Tm 2,6). „Niejako sakramentalność” Kościoła nabiera szczególnego znaczenia w świetle powierzenia mu władzy sakramentalnej skoncentrowanej wokół Ostatniej Wieczerzy i ustanowienia Eucharystii (por. Mt 26,26-28; Mk 14,22-24; Łk 22,19-20) ${ }^{63}$.

Z objawienia Nowego Testamentu wyłaniają się kolejne obrazy i figury pozwalające odkrywać eklezjalną duchowość komunijną ${ }^{64}$. Bez wątpienia do nich należy obraz zaczerpnięty z nauczania św. Pawła (por. Kol 1,15-18; Rz 12,5; 1 Kor 12,12), czyli Mistyczne Ciało Chrystusa, w którym On jest Głową. Jest ono obdarowane bogactwem różnorodności charyzmatów, powołań, funkcji, darów. Z tego względu sposób życia i rozwój, który winien mieć charakter chrystocentryczny oraz uchrystusowiony, posiada realny wpływ na jego kształt wewnątrzeklezjalny, a także na postrzeganie go przez tych, którzy są poza nim ${ }^{65}$. Nie ogranicza się zatem jedynie do pewnej figury, ale odzwierciedla charakter komunijny wertykalno-horyzontalny, cechujący się powszechnością oraz otwartością ${ }^{66}$ W ten sposób coraz

62 W swoim nauczaniu Kościół określa się następująco: Cum autem Ecclesia sit in Christo veluti sacramentum seu signum et instrumentum intimae cum Deo unionis (KK 1). Kluczowym pojęciem jest łacińskie słowo veluti - niejako. Wyjątkowość jego polega na tym, że nie może być Kościół traktowany w sensie ścisłym jako sakrament, ponieważ albo należałoby przyjąć, że jest to ósmy odrębny sakrament, albo że jest to sakrament nadrzędny w stosunku do pozostałych, a wówczas stają się one niekonieczne do zbawienia.

63 Por. Y. Congar, This Church, 41-43; R. Skrzypczak, „Kościół”, 178.

64 Por. K.-W. Niebuhr, „Biblisch-theologische”, 106.

65 Por. R. Skrzypczak, „Kościół”, 180.

66 Por. KK 7. 
bardziej można uświadomić sobie swoją tożsamość eklezjalną, która przekracza rozumienie strukturalno-przestrzenno-administracyjne ${ }^{67}$.

Bez wątpienia jednym z centralnych i najbardziej rozbudowanym opisem, którym posługuje się Vaticanum II, jest określenie Kościoła jako „Ludu Bożego" ${ }^{68}$. Odzwierciedla misterium, które zaistniało pomiędzy ludem wybranym (por. Jr 31,31-34), a obecnie urzeczywistnia się pomiędzy Chrystusem a całym Kościołem (por. 1 P 2,9-10) w różnorodności jego bogactwa charyzmatycznego opartego na powołaniu kapłańskim, prorockim oraz królewskim ${ }^{69}$.

67 Por. J. Ratzinger, Kościół. Pielgrzymująca wspólnota wiary, 238-240. Y. Congar, idąc za Journetem, stwierdza: ,the visibility of the Church and her spirituality grow at the same time and are inseparable": Y. Congar, This Church, 36.

68 J. Ratzinger podkreśla częste użycie tego terminu w Nowym Testamencie, jednakże nie zawsze można go odnosić do identyfikacji z Kościołem. O wiele częściej, jego zdaniem, odzwierciedla on „,nowego Izraela”, którym stali się chrześcijanie. Uważa też za absurdalne myślenie, iż umieszczenie w Lumen gentium części o ludzie Bożym prowadzi do wniosku dotyczącego zmiany w relacji hierarchii do laikatu. Por. J. Ratzinger, „Kościół - znak wśród narodów”, 249-250. Y. Congar w tym kontekście wyjaśnia wątpliwość nakreśloną przez J. Ratzingera i dotyczącą niebezpieczeństwa pełnej identyfikacji Kościoła posiadającego także wymiar ludzki z Osobą Jezusa Chrystusa. Odwołując się do roli Ducha Świętego w eklezjogenezie, stwierdza: „The gift of the Spirit as principle of the life of the Church changes the conditions under which we can talk, in regard to her, of sin, prevarication and penance. In one way or another, it makes it necessary to introduce a distinction between the Church as a definite superpersonal reality united to Christ with the bonds of indestructible alliance - Spouse, Body of Christ - and the Church as a congregation of Christians who, all and each, are weak and sinners, in which case we can talk, with Don Vonier, of «People of God»»: Y Congar, This Church, 34. Por. W. Kućko, „Braterstwo”, 130.

${ }_{69}$ Por. KK 11-14. Jak stwierdza J. Ratzinger, idea Kościoła jako „Ciała Chrystusowego" według teologów niemieckich nie do końca wyjaśniała relację widzialnego wymiaru Kościoła oraz niewidzialnego, a także prawa w stosunku do łaski oraz organizacji i życia. W związku z tym o wiele trafniejsze określenie to „lud Boży”. Równie istotnym problemem, który należało rozstrzygnąć, była identyfikacja Kościoła z Jezusem Chrystusem. Por. J. Ratzinger, „Kościół - znak wśród narodów”, 245. Y. Congar stwierdza, że pojęcie „ludu Bożego” posiada swoją genezę w uprawianej teologii katolickiej w latach 1937-1942. Przede wszystkim chodziło o poszukiwanie ciągłości Izraela w Kościele i osadzenie go w szerszej perspektywie historiozbawczej. Autor przypisuje genezę tego pojęcia Akcji Katolickiej oraz ruchowi liturgicznemu. Wykazuje opinie Dom Anschiare Vonier, który uważał, że pojęcie Kościół reprezentuje kierunek sakramentalny i kultyczny zaś „lud Boży” 
W tym kontekście nauka Kościoła wykazuje bardzo szeroką perspektywę powołania do niego. Opierając się na słowach ewangelicznych (por. Łk 1,35; Mk 1,24; Łk 4,34; J 6,69) oraz nauczaniu św. Pawła (por. 1 Tes 4,3; Ef 1,4), a także na swoich początkach (por Dz 2,42-47), postuluje ewangeliczną otwartość na świat, w którym wypełnia misję Chrystusa. Powszechność powołania do „Ludu Bożego” należy jednoznacznie łączyć z przełomowym stwierdzeniem soborowym dotyczącym powszechnego powołania do świętości ${ }^{70}$. O komunijnej świadomości „Ludu Bożego” świadczy posłuszeństwo Chrystusowi, które nie pozwala pozostawać Kościołowi w zamkniętej enklawie. Można stwierdzić, że Kościół o tyle jest wierny swojej naturze, o ile pozostaje misyjny oraz misjonarski ${ }^{71}$, a także staje się żywym świadectwem ${ }^{72}$.

\section{Zakończenie}

Współczesne wyzwania, z którymi spotyka się Kościół, stają się istotną przyczyną poszukiwania i odczytywania na nowo jego tożsamości. Problem ten dotyka zarówno Kościoła jako całości, jak również każdego wierzącego w indywidualnym wymiarze jego rozwoju w wierze. Ostatecznym celem powołania człowieka jest pełnia zjednoczenia z Bogiem w doświadczeniu eschatologicznym. Droga do tego celu prowadzi poprzez doświadczanie pewnego stopnia tego

wyraża życie ludzkości oddane Bogu. Z kolei F.B. Norris zauważa, że lud Boży został ukształtowany przez Niego samego, a dzięki Niemu dokonała się transformacja w Kościół dzięki Wcieleniu i Zesłaniu Ducha Świętego. Y. Cogar wskazuje na zasługi teologów niemieckich, którzy przyczynili się do rozwoju tego pojęcia (M. Schmaus, I. Baces, D. Koster). Por. Y. Congar, This Church, 9-17; R. Skrzypczak, „Kościół”, 168-173.

70 Por. KK 39; W. Kućko, „Braterstwo”, 126.

71 Por. M. Tatar, „Jedność”. Rozróżnienie to wynika z charakteru Kościoła, który ze swojej natury jest misyjny, a jednocześnie jest misjonarski, tzn. wykonujący dzieła misyjne poprzez apostolską działalność misjonarską.

72 Por. Y Congar, This Church, 19: „This People possesses a life and marches towards a goal established by God. It was chosen, instituted and consecrated by God to be His servant and His witness. The people of God is like a sacrament of solvation offered to the world”. Por. także M. Tatar, „Misyjne”, 67-89; R. Skrzypczak, „Kościół”, 180-183. 
zjednoczenia już w życiu doczesnym. Nie bez znaczenia zatem pozostaje objawienie Starego Testamentu, wskazujące na miłosną inicjatywę Boga objawiającą się w wymiarze historiozbawczym. Tajemnice Wcielenia, a także Odkupienia szczególnie odsłaniają prawdę o komunijnym wejściu Boga w życie człowieka. Fakt ten objawia przede wszystkim Nowy Testament. Kluczową rolę w tym procesie odgrywa Kościół ustanowiony przez Jezusa Chrystusa, który jest jego Głową. Można zatem stwierdzić, że Kościół jest przestrzenią uświęcającego communio Boga z człowiekiem, ponieważ przekazuje słowo Boga oraz uobecnia Go w życiu sakramentalnym - w sposób szczególny w Eucharystii. To prowadzi nas do wniosku, że tożsamość eklezjalna wymaga ewangelicznego kształtowania świata i otaczającej nas rzeczywistości, a nie poszukiwania sposobów przystosowania do niej ${ }^{73}$.

\section{Biblical Foundations of the Ecclesial Spirituality of communio}

Abstract: The process of secularization and relativization of modern man's life touches the believers in their experience of the Church. At the same time, there is a noticeable interest in spirituality, but often of an individualized and non-religious nature. Hence, the necessity arises to reflect on the proper understanding of the identity of the Church. The appropriate concept for describing this identity is communio. The article explains its proper understanding in the biblical key due to the ambiguity that occurs in publications in the field of theology, as well as in non-theological sciences. It acquires a special meaning in the theology of spirituality, by defining the character of unity between God and man. The analysis of the Old Testament reveals essential aspects of the communion arising from the covenant. The analysis of the New Testament shows that the fullness of communion was accomplished in Jesus Christ, and it finds its continuation in the Church. Therefore, Christians' spirituality should be interpersonal, Christocentric, Christoformic and ecclesial. This process shapes moral life, reflected in individual, social, economic and even political life.

Keywords: biblical spirituality, ecclesial spirituality, Christian spirituality, holiness, communio, union, mysticism

\section{Bibliografia}

Augustyn z Hippony, De civitate Dei.

Augustyn z Hippony, In Evangelium Johannis tractatus.

Bartnik, C., Dogmatyka, t. II, Lublin 2003.

Benedykt XVI, Adhortacja apostolska Verbum Domini, Rzym 30.09.2010.

73 Por. W. Kućko, „Braterstwo”, 150. 
Bracken, J.A., „Community”, w: The New Dictionary of Theology, J.A. Komonchak, M. Collins, D.A. Lane (red.), Dublin 1990, 216-218.

Congar, Y., Diversités et communion, Paris 1982.

Congar, Y., Lay People in the Church: A Study for the Theology of Laity, Westminster 1965.

Congar, Y., This Church that I love, L. Delafuente (tłum.), New Jersey 1969.

Czaja, A., „Communio w eklezjologii Soboru Watykańskiego II”, w: Communio w chrześcijańskiej refleksji o Kościele, A. Czaja, M. Marczewski (red.), Lublin 2004, 109-133.

Dzidek, T., Mistrzowie teologii, Kraków 1998.

Fabris, R., „Wprowadzenie”, w: Historia duchowości, t. II, Duchowość Nowego Testamentu, R. Fabris (red.), K. Stopa (tłum.), Kraków 2003, 5-14.

Fanuli, A., „Wprowadzenie”, w: Historia duchowości, t. I, Duchowość Starego Testamentu, A. Fanuli, J.L. Sicre-Diaz, M. Gilbert, R. Cavedo, G. Ravasi (red.), M. Pierzchała (tłum.), Kraków 2002, 7-15.

Forte, B., Istota chrześcijaństwa, K. Kozak (tłum.), Lublin 2007.

Grossi, V., „Duchowość łacińskich Ojców Kościoła”, w: Historia duchowości, t. III, Duchowość Ojców Kościoła, T. Špidlik, I. Gargano, V. Grossi (red.), K. Franczyk, J. Serafin, K. Stopa (tłum.), Kraków 2004, 183-430.

[Św.] Ignacy Antiocheński, Do Kościoła w Magnezji, w: Pierwsi świadkowie, Kraków 1998, 120-123.

Jagodziński, M., Komunijna wizja Kościoła wedtug Medarda Kehla SJ, Kraków 2009.

Jagodziński, M., „Komunijno-trynitarna pozycja Ducha Świętego”, Roczniki Teologiczne 66 (2019) z. 7, 5-15.

Jagodziński, M., Sakramenty w stużbie communio, Warszawa 2008.

Jan Paweł II, List apostolski Novo millennio ineunte, Rzym 06.01.2001.

Jelonek, T., Teologia biblijna, Kraków 2011.

[San] Juan De la Cruz, Subida del Monte Carmelo, w: Obras completas, Burgos 2010, 143-527.

Katechizm Kościoła Katolickiego, Poznań 1994.

Kompendium Nauki Społecznej Kościoła, J. Kupny (red.), Kielce 2005.

Kongregacja Nauki Wiary, List do Biskupów Kościoła Katolickiego o niektórych aspektach Kościoła pojętego jako komunia Communionis notio, AAS 85 (1993), 838-850.

Korpanty, J. (red.), Słownik tacińsko-polski, Warszawa 2001.

Kućko, W., „Braterstwo w nauczaniu papieża Franciszka”, Collectanea Theologica 90 (2020) $\mathrm{nr}$ 3, 123-162.

Kudasiewicz, J., Powołanie do służby. Szkice z teologii i duchowości biblijnej, Lublin 2011.

Mejzner, M., „Lektura patrystyczna Pisma Świętego”, w: Apostolat stowa Bożego, M. Kowalczyk (red.), Warszawa 2010, 40-53. 
Mickiewicz, F., „Objawienie Boga w słowie. Biblia jak słowo Boże”, w: Apostolat słowa Bożego, M. Kowalczyk (red.), Warszawa 2010, 23-39.

Morwood, M., Tomorrow's Catholic: Understanding God and Jesus in a New Millennium, London 2006.

Niebuhr, K.-W., „Biblisch-theologische Grundlagen des Communio-Begriffs im Zusammenhang der Ekklesiologie mit besonderem Bezug auf «Communio Sanctorum»", Kerygma und Dogma 50 (2004), 90-125.

Paweł VI, Encyklika Ecclesiam suam, Rzym 06.08.1964.

Ratzinger, J., Kościót. Pielgrzymujaca wspólnota wiary, S. Otto, V. Pfnür (red.), W. Szymona (tłum.), Kraków 2005.

Ratzinger, J., „Kościół - znak wśród narodów”, w: Opera omnia, t. VIII/1, K. Góźdź, M. Górecka (red.), W. Szymona (tłum.), Lublin 2013.

Ratzinger, J., „Lud i Dom Boży w nauce św. Augustyna o Kościele”, w: Opera omnia, t. I, K. Góźdź, M. Górecka (red.), W. Szymona (tłum.), Lublin 2014. Skrzypczak, R., „Kościół jako misterium, communio i missio”, Warszawskie Studia Teologiczne 17 (2004), 167-184.

Sobór Watykański II, Konstytucja dogmatyczna o objawieniu Bożym Dei verbum, w: Sobór Watykański II. Konstytucje, Dekrety, Deklaracje, Poznań 2012, 350-362.

Tatar, M., „Jedność czytelnym znakiem w świadectwie misyjnym”, Lumen gentium. Zeszyty misjologiczne 31 (1/2011) nr 160, 345-360.

Tatar, M., „Misyjne przeobrażenie współczesnego Kościoła według Evangelii gaudium", w: Kościół wobec wyzwań współczesnych, M. Jagodziński, J. Wojtkun (red.), Radom 2015, 67-89.

Tatar, M., „Słowo Boże kształtujące duchowy obraz człowieka i świata”, w: Słowo Boże w Kościele, R. Kuligowski, M. Jagodziński, D. Swend (red.), Warszawa 2009, 177-188.

Tatar, M., „Wspólnotowy i wspólnototwórczy charakter modlitwy”, Collectanea Theologica 89 (2019) nr 3, 111-136.

[Santa] Teresa, Castillo interior, w: Obras completas, T. Álvarez (red.), Burgos 2014, 771-985.

Vik, J., „Communio im Kontext der Ekklesiologie des II. Vatikanischen Konzils", Studia Universitatis Babes-Bolyai Theologia Catholica Latina 63 (2018) nr 1, 68-90.

Wroński, R., „Trynitarne podstawy eklezjologii komunijnej według Wacława Hryniewicza OMI", Roczniki Teologiczne 63 (2016) z. 7, 47-63. 